\title{
Wheat and Component Intercrop Yield, Land Equivalent Ratio and Monetary Indices Influenced by Intercropping and Row Proportions
}

\author{
S.S. Kaushik ${ }^{1 *}$ and T.D. Sharma ${ }^{2}$ \\ ${ }^{1}$ Krishi Vigyan Kendra, Dahigaon, Ahmednagar, Maharashtra-414502, India \\ ${ }^{2}$ A.S.P.G. College Lakhaoti, Buland Shahar U.P., India \\ *Corresponding author
}

\section{A B S T R A C T}

\begin{tabular}{|c|c|}
\hline Keywords & \\
\hline $\begin{array}{l}\text { Wheat, Chickpea, } \\
\text { Linseed, Mustard, } \\
\text { Wheat equivalent } \\
\text { yield, Land } \\
\text { equivalent ratio, } \\
\text { Monetary return, } \\
\text { Intercropping and } \\
\text { Row proportion. }\end{array}$ & \multirow{3}{*}{$\begin{array}{l}\text { A field experiment was conducted during rabi season of } 2005-2006 \text { at } \\
\text { Krishi Vigyan Kendra, Deendayal Research Institute, Majhagawan, Satna } \\
\text { to studies on productivity and economic viability of various wheat based } \\
\text { inter cropping systems under rain fed conditions of Kaymore Plateau. The } \\
\text { experiment comprised of three intercropping treatments with different row } \\
\text { proportions chickpea, linseed and mustard. The two years study revealed } \\
\text { that the intercropping of wheat +chickpea in } 2: 2 \text { row proportions proved } \\
\text { better over other intercropping or mono-cropping system in terms of land } \\
\text { equivalent ratio (1.36) and gross return (Rs. 54099) and B:C ratio 3.64. }\end{array}$} \\
\hline Article Info & \\
\hline $\begin{array}{l}\text { Accepted: } \\
\text { 29 June } 2017 \\
\text { Available Online: } \\
\text { 10 July } 2017\end{array}$ & \\
\hline
\end{tabular}

\section{Introduction}

Wheat is a major staple food crop of India and is of paramount importance for food security of the country. It has been a staple food with the level of consumption largely unaffected by changes in its prices and the price of substitutes like rice, maize and millets.

The current position of production and consumption of both pulses and edible oils in the country clearly shows that there is a big gap between domestic production and consumption which is filled by imports (Ali and Shiv Kumar, 2007 and Hegde, 2007). To meet the challenges of pulses and oilseed production, there is a need to adopt strategy which involves enhancing production through area expansion and productivity improvement through better adoption of improved technologies.

Intercropping ensures risks against the crop failure due to adverse weather or market fluctuations besides satisfying the dietary requirement of the explosively growing population.

The ways of increasing production are either expansion in area or improvement in productivity. In general, there is hardly any scope to bring additional area exclusively 
under pulses or oilseeds or even wheat as the demand of land for other crops will continue to rise. Thus there is only way to left is improvement in productivity of crops. Besides, other techniques, intercropping systems of growing two or more crops together on the same piece of land simultaneously may play an important role particularly under rain fed situation, where risk is more in mono cropping system.

Hegde (2007) also suggested that there is considerable scope to bring large area under oilseed through intercropping system. Similar case may be with pulses.

The success of inter cropping depends mainly on the use of compatible crops and their suitable row proportions. Inter crops with main crops are grown in two ways of additive and replacement series. In additive series, additional population of intercrops is adjusted with full population of main crop per unit area, while in replacement series, population or rows of main crops are replaced by inter crop.

In densely sown crop like wheat, particularly under rain fed conditions, inter cropping through replacement series is generally practiced and is viable. Results at various locations indicated that planting geometry plays an important role in optimizing yield levels in inter cropping systems, which may vary with crop combinations, varieties and locations.

Growing of crop without any fixed geometry was always inferior than inter cropping with appropriate geometry of planting.

\section{Materials and Methods}

A field experiment was conducted at research farm of Krishi Vigyan Kendra Majhagawan, Satna, Madhya Pradesh during for two consecutive rabi seasons of 2005 and 2006. The experiment was laid out in Randomized Block Design with 3 replications and 13 different treatments combinations with three row proportions $(2: 2,4: 2,6: 2)$, three intercropping (wheat + chickpea, wheat + linseed, wheat + mustard) and four sole crop i.e. wheat, chickpea, linseed and mustard. The objective of experiment was to study the effect of various wheat based intercropping system on yield, land equivalent ratio and monetary indices under different row proportions.

The soil of experimental area was sandy loam in texture and shallow in depth and soil was very low in available nitrogen, low in available phosphorus and higher in available potassium. Soil class was sandy loam and reaction was almost neutral. The location has subtropical climate characterized by hot dry summer and cool winter. The mean annual rainfall received during the experimental year varies from $600 \mathrm{~mm}$ to $850 \mathrm{~mm}$.

The varieties selected for wheat (HD-2285), chickpea (Uday), linseed (JLS-9) and for mustard (Rohini) The crop was sown on 19 November 2005 and 14 November 2006. The seed rate of intercrops was decided according to row proportions. Weeding was done to conserve soil moisture through dust mulch created by hand weeding after one month of sowing during both years.

Thinning operation was adopted in linseed and mustard crop. The crop was harvested on 22.03.2006 and 20.03.2007.

\section{Results and Discussion}

\section{Total yield}

Total yield of component crops in intercropping system was recorded higher in comparison of sole crop. The actual yield 
recorded under wheat + chickpea with 2:2 row ratio was highest (40.97 q/ha) whereas lowest $(26.7 \mathrm{q} / \mathrm{ha})$ under wheat + mustard with 2:2 row ratio. However expected yield recorded under these treatment was 29.83 q/ha and $27.02 \mathrm{q} / \mathrm{ha}$, respectively. Thus total increase over expected was $11.14 \mathrm{q} / \mathrm{ha}$ or $37.34 \%$ and (-) $0.32 \mathrm{q} / \mathrm{ha}$ or (-) $1.18 \%$, respectively.

Growth and yield parameters viz. plant height, dry matter accumulation, grains/spike and grain and straw yield of main crop-wheat was found to be significant under intercropping treatments (Table 1) (Singh and Turkhade (1989) and Singh et al., (1995), respectively). Pod/capsule/ siliquae /plant observed significantly highest in all the crops under all the row ratio and same was the case of yield and stover of all the crops in each row ratio.

The grain and straw yield per unit area were obtained significantly higher in sole crop of wheat than in intercropping system (Table 1). These higher yields are attributed mainly to higher production of wheat in sole stand than in intercropping, as the intercropping was followed in replacement series. Higher yields of wheat per unit are in sole crop than in intercropping system have also been reported by various workers like Sharma et al., (1987).

As regards row ratio of wheat +intercrops could not affect the growth contributing characteristic viz. Plant height, dry matter accumulation and leaf area index but grain and straw yield significantly influenced by row ratio (Table 1) (Tomar et al., 1997 and Hiremath et al., 1991). Plant height of chickpea was found to be significant and recorded maximum under $2: 2$ row ratio but less then sole crop of chickpea. Whereas 4:2 row ratio gave highest yield with linseed. Dry matter accumulation increased with each wider row ratio (6:2) and produced significantly higher over sole crop of chickpea and mustard but non-significant in case of linseed. Wheat + intercrops 6:2 row ratio produced significantly highest wheat yields, while 2:2 row ratio produced significantly lowest yields. These yields are attributed directly to plant population of wheat under different row ratios. Similar results have been reported by Hosmani et al., (1995) and Mandal et al., (1996)

Interaction effect of row proportions and intercropping was found to be significant in case of dry matter accumulation $(\mathrm{g}) / 10 \mathrm{~cm}$ row length under wheat +linseed intercropping with 4:2 row ratio (Table 2). Whereas leaf area index of wheat was found to be maximum at 60 DAS under wheat + chickpea with 2:2 row ratio (Table 3 ).

However grain and straw yield was recorded maximum under wheat +linseed with $4: 2$ row proportion (Table 4). It may be supported by the work of Willey (1979) who reported that maximizing intercropping advantages is a matter of maximizing the degree of complimentarity between the component crops.

\section{Wheat equivalent yield}

Wheat equivalent yield was also computed significantly highest under the treatments of wheat + chickpea $(46.04 \mathrm{q} / \mathrm{ha})$ intercropping than sole wheat $(39.94 \mathrm{q} / \mathrm{ha})$ and other intercropping treatments (sole chickpea 27.62 q/ha, sole linseed $26.82 \mathrm{q} / \mathrm{ha}$ and sole mustard $25.40 \mathrm{q} / \mathrm{ha}$ ) (Table 6). These are attributed to higher yield of both component crops because of better compatibility for resource utilization. These results confirm the findings of Singh et al., (1992), Wheat equivalent yield increased with each wider row ratio in wheat, linseed or mustard intercropping but reduced in wheat +chickpea intercropping numerically. These findings are in collaboration with Mallik et al., (1993), 
Table.1 Seed yield (q/ha) of both (main and component) crops under different treatments (Pooled data for 2 years)

\begin{tabular}{|c|c|c|c|c|c|c|c|c|c|c|c|c|}
\hline \multirow[t]{3}{*}{ Treatments } & \multicolumn{4}{|c|}{ Grain yield of wheat } & \multicolumn{4}{|c|}{ Seed yield of intercrop } & \multicolumn{4}{|c|}{ Total seed yield of both crops } \\
\hline & \multirow[t]{2}{*}{$\begin{array}{c}\text { Actual } \\
\text { yield }\end{array}$} & \multirow[t]{2}{*}{$\begin{array}{c}\text { Expected } \\
\text { yield }\end{array}$} & \multicolumn{2}{|c|}{$\begin{array}{c}\text { Yield increase } \\
\text { over expected } \\
\text { yield }\end{array}$} & \multirow[t]{2}{*}{$\begin{array}{l}\text { Actual } \\
\text { yield }\end{array}$} & \multirow[t]{2}{*}{$\begin{array}{c}\text { Expected } \\
\text { yield }\end{array}$} & \multicolumn{2}{|c|}{$\begin{array}{c}\text { Yield increase } \\
\text { over expected } \\
\text { yield }\end{array}$} & \multirow[t]{2}{*}{$\begin{array}{c}\text { Actual } \\
\text { yield }\end{array}$} & \multirow[t]{2}{*}{$\begin{array}{c}\text { Expected } \\
\text { yield }\end{array}$} & \multicolumn{2}{|c|}{$\begin{array}{c}\text { Yield increase } \\
\text { over expected } \\
\text { yield }\end{array}$} \\
\hline & & & $(\mathbf{q} / \mathbf{h a})$ & $(\%)$ & & & (q/ha) & $(\%)$ & & & $(q / h a)$ & $(\%)$ \\
\hline Sole wheat & 39.94 & 39.94 & & & & & & & 39.94 & 39.94 & & \\
\hline Wheat+chickpea(2:2) & 28.3 & 19.97 & 8.33 & 41.71 & 12.67 & 9.86 & 2.81 & 28.5 & 40.97 & 29.83 & 11.14 & 37.34 \\
\hline Wheat+linseed(2:2) & 21.22 & 19.97 & 1.25 & 6.26 & 6.66 & 6.09 & 0.57 & 9.36 & 27.88 & 26.06 & 1.82 & 6.98 \\
\hline Wheat+mustard(2:2) & 16.16 & 19.97 & $(-) 3.81$ & $(-) 19.08$ & 10.54 & 7.05 & 3.49 & 49.5 & 26.7 & 27.02 & $(-) 0.32$ & $(-) 1.18$ \\
\hline Wheat+chickpea(4:2) & 33.68 & 26.76 & 6.92 & 25.86 & 8.52 & 6.51 & 2.01 & 30.88 & 42.2 & 33.27 & 8.93 & 26.84 \\
\hline Wheat+linseed $(4: 2)$ & 29.64 & 26.76 & 2.88 & 10.76 & 4.64 & 4.02 & 0.62 & 15.42 & 34.28 & 30.78 & 3.5 & 11.37 \\
\hline Wheat+mustard $(4: 2)$ & 24.25 & 26.76 & $(-) 2.51$ & $(-) 9.38$ & 7.11 & 4.66 & 2.45 & 52.57 & 31.36 & 31.42 & $(-) 0.06$ & $(-) 0.19$ \\
\hline Wheat+chickpea(6:2) & 35.75 & 29.95 & 5.8 & 19.37 & 6.56 & 4.93 & 1.63 & 33.06 & 42.31 & 34.88 & 7.43 & 21.3 \\
\hline Wheat+linseed(6:2) & 34.24 & 29.95 & 4.29 & 14.32 & 3.42 & 3.05 & 0.37 & 12.13 & 37.66 & 33 & 4.66 & 14.12 \\
\hline Wheat+mustard(6:2) & 28.79 & 29.95 & $(-) 1.16$ & $(-) 3.87$ & 5.4 & 3.53 & 1.87 & 52.97 & 34.19 & 33.48 & 0.71 & 2.12 \\
\hline S.Ed. + & 1.24 & & & & & & & & & & & \\
\hline C.D. $(\mathrm{P}=0.05)$ & 2.5 & & & & & & & & & & & \\
\hline \multicolumn{13}{|l|}{ Sole intercrop } \\
\hline Chickpea & & & & & 19.73 & & & & 19.73 & & & \\
\hline Linseed & & & & & 12.19 & & & & 12.19 & & & \\
\hline Mustard & & & & & 14.11 & & & & 14.11 & & & \\
\hline
\end{tabular}


Table.2 Land equivalent ratio, gross income (000 Rs. /ha), net income (000 Rs. /ha) and Benefit: cost ratio under different treatments (Pooled data for 2 years)

\begin{tabular}{|l|c|c|c|c|}
\hline \multicolumn{1}{|c|}{ Treatments } & $\begin{array}{c}\text { Land } \\
\text { equivalent ratio }\end{array}$ & $\begin{array}{c}\text { Gross income } \\
(\mathbf{0 0 0} \text { Rs/ha) }\end{array}$ & $\begin{array}{c}\text { Net income } \\
(\mathbf{0 0 0} \text { Rs/ha) }\end{array}$ & B:C ratio \\
\hline Sole wheat & 1 & 47.582 & 36.882 & 3.45 \\
\hline Wheat + chickpea(2:2) & 1.36 & 54.099 & 42.429 & 3.64 \\
\hline Wheat + linseed(2:2) & 1.08 & 41.335 & 30.52 & 2.84 \\
\hline Wheat + mustard(2:2) & 1.16 & 41.038 & 30.203 & 2.79 \\
\hline Wheat + chickpea(4:2) & 1.27 & 52.72 & 41.232 & 3.59 \\
\hline Wheat + linseed(4:2) & 1.12 & 46.486 & 35.687 & 3.31 \\
\hline Wheat + mustard(4:2) & 1.11 & 43.957 & 33.119 & 3.06 \\
\hline Wheat + chickpea(6:2) & 1.23 & 52.078 & 40.718 & 3.59 \\
\hline Wheat + linseed(6:2) & 1.14 & 48.78 & 37.952 & 3.5 \\
\hline Wheat + mustard(6:2) & 1.1 & 45.907 & 25.07 & 3.24 \\
\hline S.Ed. +. & 0.06 & 2.466 & 1.914 & 0.17 \\
\hline C.D.(P=0.05) & 0.11 & 4.834 & 3.752 & 0.33 \\
\hline Sole intercrop & \multicolumn{3}{|l}{} & \\
\hline Chickpea & 1 & 30.346 & 19.146 & 1.71 \\
\hline Linseed & 1 & 27.795 & 19.366 & 2.09 \\
\hline Mustard & 1 & 28.306 & 19.589 & 2.15 \\
\hline
\end{tabular}

Land equivalent ratio was recorded higher in intercropping treatments of wheat + chickpea as compared to other intercropping and sole cropping treatments (Table 6). All intercropping treatments attained higher values of LER than sole crops but recorded maximum (1.36) in wheat + chickpea with $2: 2$ row ratio. Higher LER in intercropping system in general and in wheat +pulses in particular has also been reported by Singh et al., (1992). Barik et al., (2006) reported that land equivalent yield increased with each wider row ratio in wheat, linseed or mustard intercropping but reduced in wheat +chickpea and wheat + mustard intercropping numerically.

\section{Monetary reurn}

Net income and benefit: cost ratio was computed significantly higher in the intercropping treatments of wheat +chickpea than all other treatments (Table 6). Net return and benefit: cost ration under wheat +chickpea with 2:2 row ratio was recorded Rs. 42429/ha and 3.64 in comparison of sole wheat, sole chickpea, sole linseed and sole mustard Rs.36882 and 3.45, Rs.19146 and 1.71, Rs.19366 and 2.09, Rs.19589 and 2.15, respectively. These results may very well supported by the findings Singh et al., (1992.The intercropping treatment of wheat +chickpea being at par with wheat +linseed in $6: 2$ row ratio and with sole wheat, attained higher values of $\mathrm{B}: \mathrm{C}$ ratios than all other treatments (Table 3). These are attributed to higher net income in wheat +chickpea intercroppings and to combined effects of lower cost and higher income in case of wheat +linseed in 6:2 row ratio and sole wheat treatments. Findings of Singh et al., (1992) and Srivastav and Bohra (2006) are in agreement to the results of present investigation in this respect.

\section{References}

Balyan, J.S.1997. Performance of maize (Zea mays) based intercropping systems and their after effect on wheat (Triticum aestivum). In

Proceedings of National Symposium on 
Cropping Systems (M. Pal, Ed.) held at CSSRI, Karnal, 3-5 April, 1995.

Barik, P., Midya, A., Sarkar, B.K. and Ghasa, S.S.2006. Wheat and chickpea intercropping systems in an additive series experiment: advantages and weed smothering. European Journal of Agronomy 24(4): 325-332.

Hegde, D.M.2007. Oilseeds: Increasing production area. The Hindu Survey of Indian Agriculture. pp. 42-45.

Hosmani, M.M., Chittapur, B.M. and Hiremath, S.M. (Eds) 1990 Intercropping Principles and Practices, University of Agricultural Sciences, Dharwad.

Mallik, A., Verma, U.N., Thakur, R. and Srivastav, V.C.1993.Productivity of wheat (Triticum aestivum) based intercropping system under limited irrigation. Indian Journal of Agronomy 38 (2): 178-181.

Mandal, B.K., Das, D., Saha, A. And Mohasin, M.D.1996. Yield advantages of wheat (Triticum aestivum) and chickpea (Cicer arietinum) under different spatial arrangements in intercropping. Indian Journal of Agronomy 41 (1): 17-21.

Mishra, B.2007. Wheat: quality based procurement. The Hindu Survey of Indian Agriculture. pp. 32-35.

Reddy, S.R. 2004. Cropping systems, resource use and plant interaction: competitive relationships. Principles of Crop Production. Kalyani Publishers, New Delhi. pp. 531-532.

Sharma, R.P., Roy, R.K., Singh, A.K., and Jha, R.N. 1987. Production potential of wheat and gram in sole and mixed /intercropping systems. Indian Journal of Agronomy 32(3): 235-237.

Singh, A., and Turkhade, B.B.1989. Fertilizer management in wheat+linseed intercropping system under rain fed conditions. Indian Journal of Agronomy 34(3): 297-301.

Singh, A and Turkhade, B.B., Prasad, R., Singh, R.K., Singh, K.D. and Bhargava, S.C.1992.Effect of wheat (Triticum aestivum) + linseed (Linum usitatissimum) intercropping on moisture use. Indian Journal of Agronomy 37 (1): 142-143.

Srivastav, R.K. and Bohra, J.S. 2006. Performance of wheat (Triticum aestivum), and Indian mustard (Brassica juncea) intercropping in relation to row ratio, Indian mustard variety and fertility levels. Indian Journal of Agronomy 51(2): 107-111.

Tomar, S.K., Singh, H.P. and Ahlawat, I.P.S.1997. Dry matter accumulation and $\mathrm{N}$ uptake in wheat (Triticum aestivum) based intercropping systems as affected by $\mathrm{N}$ fertilizer. Indian Journal of Agronomy 42 (1): 33-37.

Willey, R.W.1979. Intercropping: Its importance research needs Part-I: Competition and yield advantages. Field Crop Abstract 32:1-10.

Yadav, R.L., Prasad, K. and Dwivedi, B.S. 1998. Cropping System Research. Fifty years of Agronomic Research in India. Edited Yadav, R.L., Singh, Punjab, Prasad, R. and Ahalawat, I.P.S. A publication of Indian Society of Agronomy, New Delhi pp. 193-220.

\section{How to cite this article:}

Kaushik, S.S. and Sharma, T.D. 2017. Wheat and Component Intercrop Yield, Land Equivalent Ratio and Monetary Indices Influenced by Intercropping and Row Proportions. Int.J.Curr.Microbiol.App.Sci. 6(7): 2626-2631. doi: https://doi.org/10.20546/ijcmas.2017.607.370 